\author{
방사선을 이용한 실란 가교구조의 유/무기 복합 수소이온 \\ 교환막 제조 및 연료전지 성능 평가 \\ 이지홍* · 손준용* · 신동원** · 송주명* · 이영무** · 노영창* · 신준화*, \\ *한국원자력연구원 첨단방사선연구소 공업환경연구부, \\ **한양대학교 화학공학과 \\ (2012년 3월 8일 접수, 2012년 4월 5일 수정, 2012년 4월 5일 채택)
}

\title{
Fabrication of Silane-crosslinked Proton Exchange Membranes by Radiation and Evaluation of Fuel Cell Performance
}

\author{
Ji-Hong Lee*, Joon-Yong Sohn*, Dong-Won Shin**, Ju-Myung Song*, Young-Moo Lee**, \\ Young-Chang Nho*, and Junhwa Shin*,† \\ *Research Division for Industry and Environment, Advanced Radiation Technology Institute, \\ Korea Atomic Energy Research Institute, 1266 Sinjeong-dong, Jeongeup-si, Jeollabuk-do 580-185, Korea \\ **Department of Chemical Engineering, College of Engineering, Hanyang University, Seoul 133-791, Korea \\ (Received March 8, 2012; Revised April 5, 2012; Accepted April 5, 2012)
}

\begin{abstract}
초록: 본 연구에서는 다양한 조성의 스티렌(styrene, St)과 3-(trimethoxy)propyl methacrylate(TMSPM)를 poly(ethyleneco-tetrafluoroethylene)(ETFE) 필름에 방사선 동시조사법으로 그래프트시킨 후 졸-젤 반응 및 설폰화 반응을 진행하 여 실란 가교된 유/무기 복합막을 제조하였다. 졸-젤 반응을 통해 형성된 실란 가교 구조는 Fourier transform infrared spectroscopy(FTIR) 및 thermo gravimetric analysis(TGA)를 사용하여 관찰하였다. 설폰화 관능기를 도입하여 막을 제조한 후 유사한 이온교환용량을 가지면서 TMSPM의 함량이 다른 연료전지막을 선별하여 함수율, 치수 안정성, 수소 이온전도도 등의 물성을 측정하였다. 또한 제조된 유/무기 복합막을 이용하여 membrane electrode assemblies(MEA)를 제조한 후 단위전지 성능을 평가하였다.
\end{abstract}

\begin{abstract}
In this study, silane-crosslinked organic/inorganic composite membranes were prepared by simultaneous irradiation grafting of binary monomer mixtures (styrene and 3-(trimethoxysilyl)propyl methacrylate (TMSPM)) with various compositions onto a poly(ethylene-alt-tetraethylene) (ETFE) film and followed by sol-gel processing and sulfonation to provide a silane-crosslinked structure and a proton conducting ability, respectively. The Fourier transform infrared spectroscopy (FTIR) and thermo gravimetric analysis (TGA) were utilized to confirm the crosslinking of ETFE- $g$-PS/ PTMSPM films. The prepared membranes with similar ion exchange capacity but a different TMSPM content were selected and their membrane properties were compared. The ETFE- $g$-PSSA/PTMSPM membranes were characterized by water uptake, dimensional stability, and proton conductivity after sulfonation. The membrane electrode assemblies (MEA) of the prepared membranes were fabricated and their single cell performances were measured.
\end{abstract}

Keywords: radiation, grafting, poly(ethylene-co-tetrafluoroethylene), silane-crosslinking.

\section{서 론}

화석연료에 의한 환경오염 문제와 원유 가격의 급등으로 인하여 친환경이며 에너지 효율이 높은 연료전지가 각광받고 있다.

고분자 전해질 연료전지(PEMFC)에서 핵심소재인 고분자

'To whom correspondence should be addressed.

E-mail: shinj@kaeri.re.kr
전해질막은 듀퐁에서 개발한 불소계 고분자인 나피온(Nafion) 이 주로 사용되고 있다. 일반적으로, 나피온 전해질막은 내화 학성, 내열성, 기계적 특성이 우수하지만 고온에서 수소이온 전도도 감소 문제와 직접메탄올 연료전지에서 메탄올 연료의 높은 투과도 및 비싼 가격 등의 단점을 가지고 있다. ${ }^{1-3}$ 따라 서 이러한 나피온의 문제점을 해결하기 위해서 대체 연료전 지막 개발이 다각도로 진행되고 있으며 그 중에 방사선 그래 프트 기술을 이용한 연료전지막 제조 연구 또한 활발히 진행 되고 있다. ${ }^{4-7}$ 
방사선 그래프트를 이용한 연료전지막 제조 연구는 방사선 을 이용하여 화학적, 열적, 기계적 특성이 우수한 고분자 골 격에 수소이온 전도성 고분자를 도입하는 형태로 진행되어 왔다. ${ }^{89}$ 에너지가 높은 방사선을 활용하면 개시제를 사용하지 않기 때문에 개시제에 의한 오염이 없고, 방사선의 높은 투과 력으로 인하여 우수한 물성을 지닌 상용 필름 내부까지 원하 는 고분자를 쉽게 도입할 수 있는 장점이 있다. 또한 그래프 트되는 고분자의 양은 방사선 조사선량으로 손쉽게 제어가 가능하기 때문에 연료전지막의 물성 최적화가 용이하다. ${ }^{10,11}$

방사선을 이용하여 연료전지막을 제조할 경우 주로 불소고 분자 필름에 스티렌을 그래프트 중합시킨 후 설폰화 과정을 통해 이온전도성 작용기가 도입된 연료전지막을 제조할 수 있다. ${ }^{2}$ 하지만, 이렇게 제조된 이온교환막은 이온교환용량이 높을 경우 높은 함수율 및 팽창률을 가지게 되며 연료전지 구동 중 발생하는 라디칼에 의해 스티렌 설폰산 고분자 사슬 이 분해되는 문제점을 가지고 있다. 이와 같은 수치안정성 및 화학적 안정성 문제는 가교 구조를 도입하면 개선이 될 수 있기 때문에 주로 divinylbenzene(DVB)와 같은 가교제를 스 티렌과 동시에 그래프트시켜 가교 구조를 가지는 연료전지막 제조 연구가 주로 진행되어 왔다. ${ }^{13}$

최근에는 실란 계열의 단량체( $p$-styryltrimethoxysilane)를 polyethylene-co-tetrafluoroethylene(ETFE) 필름에 방사선을 이용하여 그래프트시킨 후 졸-젤 반응으로 실란 가교 구조를 형성하고 설폰화 과정을 통하여 실란 가교 구조의 유/무기 복합 수소이온 교환막(silane-crosslinked organic/Inorganic composite proton exchange membrane)을 제조하였다. ${ }^{14-16}$ 이러한 연구 는 가교 구조 형성으로 인한 화학적 안정성 증가와 동시에 유/무기 복합 구조 형성으로 인한 고온 안정성 및 기계적 물 성이 향상되는 장점이 있다. ${ }^{1718}$

본 연구팀에서는 선행연구를 통하여 스티렌과 졸젤 반응 으로 가교 구조를 형성할 수 있는 3-(트리메톡시실릴)프로필 메타 아크릴레이트(TMSPM)가 동시에 그래프트된 ETFE 필 름을 제조하기 위한 방사선 조사 조건을 확립하였고 설폰화 및 실란 가교 반응을 통한 실란 가교 구조의 ETFE- $g$-PSSA/ PTMSPM 연료전지막의 제조 연구를 수행하였다. ${ }^{19,20}$ 연구 결 과, 스티렌과 TMSPM 단량체 혼합 용액을 $\mathrm{ETFE}$ 필름에 방 사선으로 그래프트시킬 경우 아세톤이 최적의 용매임을 확인 하였고, TMSPM의 그래프트율이 증가할수록 제조된 막의 화 학적 안정성이 증가하는 것을 확인하였다.

본 연구에서는 선행연구를 통하여 제조된 실란 가교 구조 를 형성하는 수소이온교환막으로 연료전지의 활용 가능성을 검증하기 위하여 MEA(Membrane Electrode Assemblies)를 제작한 후 단위전지 성능을 측정하였다. 이를 위하여 유사한 이온교환용량(IEC) 값을 가지지만 실란 가교에 직접적인 영 향을 미치는 TMSPM의 함량이 다른 막들을 제조하여 단위 전지 성능 평가에 사용하였다. 스티렌과 TMSPM이 혼합되어
그래프트된 ETFE 필름의 졸젤 반응 후, FTIR(Fourier transform infrared spectroscopy)과 TGA(thermo gravimetric analysis)를 이용하여 실란 가교 구조의 형성 여부와 가교에 의한 열적 특성 변화를 관찰하였고 설폰화 반응 후에는 제조 된 막들의 수소이온전도도 및 기계적 특성 또한 관찰하였다.

\section{실 험}

시료준비. $50 \mu \mathrm{m}$ 두께의 polyethylene-co-tetrafluoroethylene (ETFE) 필름은 Asahi Glass에서 구입을 하였고, 스티렌 (St, 99\%)과 3-(트리메톡시실릴) 프로필 메타 아크릴레이트 (TMSPM)는 Aldrich에서 구입하였다. 아세톤, 1,2-디클로로 에탄, 테트라하이드로퓨란(THF)은 Showa(Japan)에서 구입하 였으며 클로로설폰산 $(98 \%)$ 은 Kanto Chemical에서 구입하였 다. 구입한 시약 및 용매는 추가 정제과정 없이 사용하였다.

방사선 그래프팅. $50 \mu \mathrm{m}$ 의 ETFE 필름을 $4 \mathrm{~cm} \times 20 \mathrm{~cm}$ 크 기로 자르고, 아세톤으로 세척하여 건조한 후 St/TMSPM 단 량체와 아세톤 용매를 혼합한 용액에 침지하였다. 필름이 침 지된 용액을 20 분간 질소로 충진하고 ${ }^{60} \mathrm{Co}$ 에서 발생되는 감 마선을 이용하여 $2 \mathrm{kGy} / \mathrm{h}$ 의 조사선량률로 정해진 선량에 따 라 조사하였다. 방사선 조사된 용액에서 그래프트된 ETFE 필름을 빼내어 $\mathrm{THF}$ 용매로 세척하여 잔류하고 있는 스티렌 및 올리고머 등을 제거하였고 진공오븐에서 $80^{\circ} \mathrm{C}$ 로 12 시간 동안 건조하였다. 그래프트된 $\mathrm{ETFE}$ 필름의 그래프트율 (DOG)은 식 (1)을 이용하여 계산하였다. $W_{\mathrm{o}}$ 는 방사선 그래프 트 전의 ETFE 필름의 건조 무게이며, $W_{\mathrm{g}}$ 는 그래프트된 ETFE 필름의 무게이다.

$$
\operatorname{DOG}(\%)=\left[\left(W_{\mathrm{g}}-W_{\mathrm{o}}\right) / W_{\mathrm{o}}\right] \times 100
$$

졸-젤 가교 및 설폰화. 제조된 ETFE-g-PS/PTMSPM 필름 은 $1.0 \mathrm{M} \mathrm{HCl}$ 용액에 담근 후 $80^{\circ} \mathrm{C}$ 에서 24 시간 동안 졸-젤 반응하여 가교 구조를 형성시켰다. 실란 가교된 필름은 증류 수로 수회에 거쳐 세척한 후 진공오븐 $80^{\circ} \mathrm{C}$ 에서 12 시간 동안 건조시켰다. 건조된 필름은 클로로설폰산/1,2-디클로로에탄(2/ $98 \mathrm{v} / \mathrm{v})$ 혼합 용매 안에 넣어 12 시간 동안 반응시키고 $70^{\circ} \mathrm{C}$ 증류수에 담궈 3 시간 동안 필름을 가수분해하여 설폰산 작용 기가 도입된 실란 가교 구조의 연료전지막(silane-crosslinked ETFE-g-PSSA/PTMSPM)을 제조하였다. 이후 제조된 연료전 지막은 증류수로 수회 세척한 후 $60^{\circ} \mathrm{C}$ 에서 진공 건조하였다.

이온교환용량(IEC: Ion Exchange Capacity) 측정. 제조 된 연료전지막의 $\mathrm{IEC}$ 는 적정 방법을 이용하여 측정하였다. 제조된 막은 $1.0 \mathrm{M} \mathrm{NaCl}$ 수용액에 24시간 동안 침지시켜 설 폰산 작용기의 수소이온을 $\mathrm{Na}$ 이온으로 치환시킨 후 용액 속 에 생성된 $\mathrm{HCl}$ 의 양을 $0.1 \mathrm{M} \mathrm{NaOH}$ 수용액으로 적정하였다. 적정에 사용된 $\mathrm{NaOH}$ 의 양을 식 (2)에 대입하여 IEC 값을 계 
산하였다. 여기서, $\mathrm{N}$ 은 적정한 $\mathrm{NaOH}$ 의 노르말 농도이고, $Y$ 는 적정된 $\mathrm{NaOH}$ 의 양 $(\mathrm{mL})$ 이며, $W_{\mathrm{o}}$ 는 시료의 건조 무게이다.

$$
\operatorname{IEC}(\mathrm{meq} / \mathrm{g})=N \times Y / W_{\mathrm{o}}
$$

\section{치수 변화(Dimensional Change) 및 함수율(Water Uptake).} $3 \mathrm{~cm} \times 3 \mathrm{~cm}$ 크기의 제조된 막을 상온에서 증류수에 24시간 동안 담근 후 충분히 수화된 막의 면적 및 무게를 측정하였 다. 수화된 막의 면적과 건조된 막의 면적을 식 (3)을 이용하 여 치수 변화를 측정하였다. 이 식에서 $A_{\mathrm{w}}$ 는 물을 함유한 막 의 면적이고, $A_{0}$ 는 건조된 막의 면적을 나타낸다.

$$
\text { Dimensional change }(\%)=\left(A_{\mathrm{w}}-A_{\mathrm{o}}\right) \times 100 / A_{\mathrm{o}}
$$

한편, 건조된 필름의 무게와 수화된 필름의 무게 차이를 이 용하여 함수율을 측정하였으며 식 (4)는 함수율 계산 방법이 다.

$$
\text { Water uptake }(\%)=\left(W_{\mathrm{w}}-W_{\mathrm{o}}\right) \times 100 / W_{\mathrm{o}}
$$

여기서, $W_{\mathrm{w}}(\mathrm{g})$ 는 물을 함유한 막의 무게이고, $W_{\mathrm{o}}(\mathrm{g})$ 는 건조 된 막의 무게를 나타낸다.

수소이온전도도(Proton Conductivity) 측정. 제조된 막의 동일한 면에 백금 $(\mathrm{Pt})$ 탐지침을 $4 \mathrm{~mm}$ 간격으로 접촉시키고 Solatron사의 SI1260을 사용하여 임피던스를 측정한 후 식 (5)를 이용하여 수소이온 전도도를 계산하였다.

$$
\sigma=W / R \times d \times l
$$

위 식에서 $\sigma(\mathrm{S} / \mathrm{cm})$ 는 수소이온도도도, $W(\mathrm{~cm})$ 는 기준 탐 지침 사이의 거리, $R(\Omega)$ 은 임피던스 측정시 고주파 영역에 서 임피던스의 허수부가 없어지는 지점의 옴저항(ohmic resistance)을 의미하며, $d(\mathrm{~cm})$ 는 막의 두께, $l(\mathrm{~cm})$ 은 막의 폭 을 의미한다. 이때, 제조된 막은 증류수에서 24 시간 동안 충 분히 수화하고 막의 표면의 물을 제거 후 상대습도 $90 \%$ 의 챔버에서 온도를 올려가며 수소이온 전도도를 측정하였다.

FTIR(Fourier Transform Infrared Spectroscopy) 분석. 졸-젤 반응으로 인한 가교구조 형성은 그래프트된 ETFE- $g$ $\mathrm{PS} / \mathrm{PTMSPM}$ 필름과 실란 가교 구조를 형성시킨 필름 (crosslinked ETFE-g-PS/PTMSPM)을 FTIR spectrometer (Brucker, Tensor-37)를 이용하여 $4000 ~ 500 \mathrm{~cm}^{-1}$ 파장 범위에 서 적외선 스펙트럼을 측정하고 비교 분석하여 관찰하였다.

기계적 성질(Mechanical Properties). 제조된 막의 기계적 물성은 INSTRON series IX(Instron, Universal Testing System Model 4400) 장비를 이용하여 측정하였다. 시편은 $5.3 \mathrm{~mm} \times 31 \mathrm{~mm}$ 크기로 준비하였고 상온에서 $50 \mathrm{~mm} / \mathrm{min}$
변형속도로 인장강도(tensile strength)와 파단 연신율(break elongation)을 측정하였다.

TGA(Thermo Gravimetric Analysis) 분석. St/TMSPM 의 함량비에 따른 열적 특성은 TA Instrument사의 SDT600 을 사용하여 관찰하였다. 약 $10 \mathrm{mg}$ 의 시료를 이용하였으며, 질소 기류 아래에서 $10^{\circ} \mathrm{C} / \mathrm{min}$ 의 승온 속도로 $650^{\circ} \mathrm{C}$ 까지 측 정하였다.

MEA(Membrane Electrode Assemblies) 제조 및 PEMFC Single Cell Performance. 백금/탄소 촉매를 $5 \mathrm{wt} \%$ Nafion 용액에 분산시켜 제조한 catalyst 잉크를 이용하여 catalyst-coated membrane $(\mathrm{CCM})$ 방법 중 스크린 프린팅 기 법으로 $\mathrm{MEA}$ 를 제조하였다. 제조된 $\mathrm{MEA}$ 와 $\mathrm{CNL}$ 에서 제조 한 single cell 모듈을 이용하여 cell performance용 single cell을 제조하였고 $100 \%$ 상대습도 및 $80{ }^{\circ} \mathrm{C}$ 조건에서 SMART PEMFC test system(WonATech)을 사용하여 cell performance 를 측정한 후 그 결과를 $\mathrm{I}-\mathrm{V}$ 곡선으로 나타내었다. 이때 음극 (anode) 방향으로 수소 가스를 $100 \mathrm{~mL} / \mathrm{min}$ 으로 주입하였으 며, 양극(catode) 방향으로는 산소 가스를 $100 \mathrm{~mL} / \mathrm{min}$ 으로 주입하였다.

\section{결과 및 토론}

Table 1은 졸-젤 반응 및 설폰화 과정을 거쳐 제조된 실란 가교 구조의 수소이온교환막 중에 유사한 이온교환용량(IEC) 값을 갖지만 $\mathrm{TMSPM}$ 의 조성비가 다른 막을 선별하여 측정 한 이온교환용량(IEC), 그래프트율(DOG), 함수율(WU), 치수 변화(DC) 값을 보여준다. 설폰화 과정에서 설폰산 작용기는 그래프트된 스티렌 고분자에 도입되기 때문에 IEC 값이 유사 하다는 것은 그래프트된 스티렌 고분자의 반복단위의 개수도 비슷하다는 것을 의미한다. 따라서 유사한 IEC 값에서 DOG 가 증가된 것은 졸-젤 반응에 참여할 수 있는 TMSPM 고분 자의 함량이 높음을 나타낸다.

TMSPM 조성비에 따른 함수율의 변화를 관찰해 보면 $\mathrm{TMSPM}$ 을 첨가하지 않은 경우보다 $\mathrm{TMSPM}$ 을 $30 \%$ 첨가하 여 제조된 막의 함수율이 증가하였고 $\mathrm{TMSPM}$ 을 $50 \%$ 첨가 하여 제조된 막의 경우 함수율이 다시 감소하고 있음을 관찰

Table 1. Characterization of Crosslinked ETFE-g-PSSA/ PTMSPM Membranes Prepared with Different Ratios of St/TMSPM

\begin{tabular}{lcccc}
\hline \multicolumn{1}{c}{ Samples name } & $\begin{array}{c}\mathrm{IEC}^{a} \\
(\mathrm{meq} / \mathrm{g})\end{array}$ & $\begin{array}{c}\mathrm{DOG}^{b} \\
(\%)\end{array}$ & $\begin{array}{c}\mathrm{WU}^{c} \\
(\%)\end{array}$ & $\begin{array}{c}\mathrm{DC}^{d} \\
(\%)\end{array}$ \\
\hline St/TMSPM 10/0 (v/v) & 2.17 & 47.7 & 69 & 55 \\
St/TMSPM 7/3 (v/v) & 2.13 & 68.2 & 81 & 65 \\
St/TMSPM 5/5 (v/v) & 2.04 & 73.0 & 64 & 52 \\
\hline
\end{tabular}

$\overline{{ }^{a} \text { Ion exchange capacity. }{ }^{b} \text { Degree of graft. }{ }^{c} \text { Water uptake. }{ }^{d} \text { Dimensional }}$ change. 
하였다. 치수변화 또한 함수율과 비슷한 경향을 보여주고 있 다. 이러한 결과들은 $30 \%$ 조성비의 TMSPM을 사용하여 제 조된 막의 경우 졸젤 반응(산 촉매 가수분해 및 축합반응) 시 실란 가교 구조 형성이 잘 이루어지지 않아 수분 흡수를 도와주는 하이드록시 실란 작용기가 존재하기 때문에 함수율 과 치수변화가 증가된 것으로 여겨지며 반면, $50 \%$ 조성비의 TMSPM을 사용할 경우 그래프트된 TMSPM 고분자 함량이 증가하여 실란 가교 형성이 잘 이루어지게 되어 $30 \%$ 조성비 의 TMSPM으로 제조된 막보다 함수율과 치수변화가 감소되 는 것으로 여겨진다. ${ }^{20}$

졸젤 반응으로 인한 실란 가교 구조 형성 과정은 FTIR 스 펙트럼을 통하여 관찰할 수 있다. Figure 1은 순수한 ETFE 필 름, $50 \%$ 조성비의 $\mathrm{TMSPM}$ 을 사용하여 그래프트시킨 필름 (ETFE- $g$-PS/PTMSPM)과 졸-젤 반응으로 실란 가교 구조를 형성시킨 필름(crosslinked ETFE-g-PS/PTMSPM)의 FTIR 스펙트럼을 보여준다.

ETFE-g-PS/PTMSPM 필름의 FTIR 스펙트럼에서는 TMSPM 이 그래프트되면서 나타나는 메톡시 그룹 $\left(-\mathrm{OCH}_{3}\right)$ 진동피크
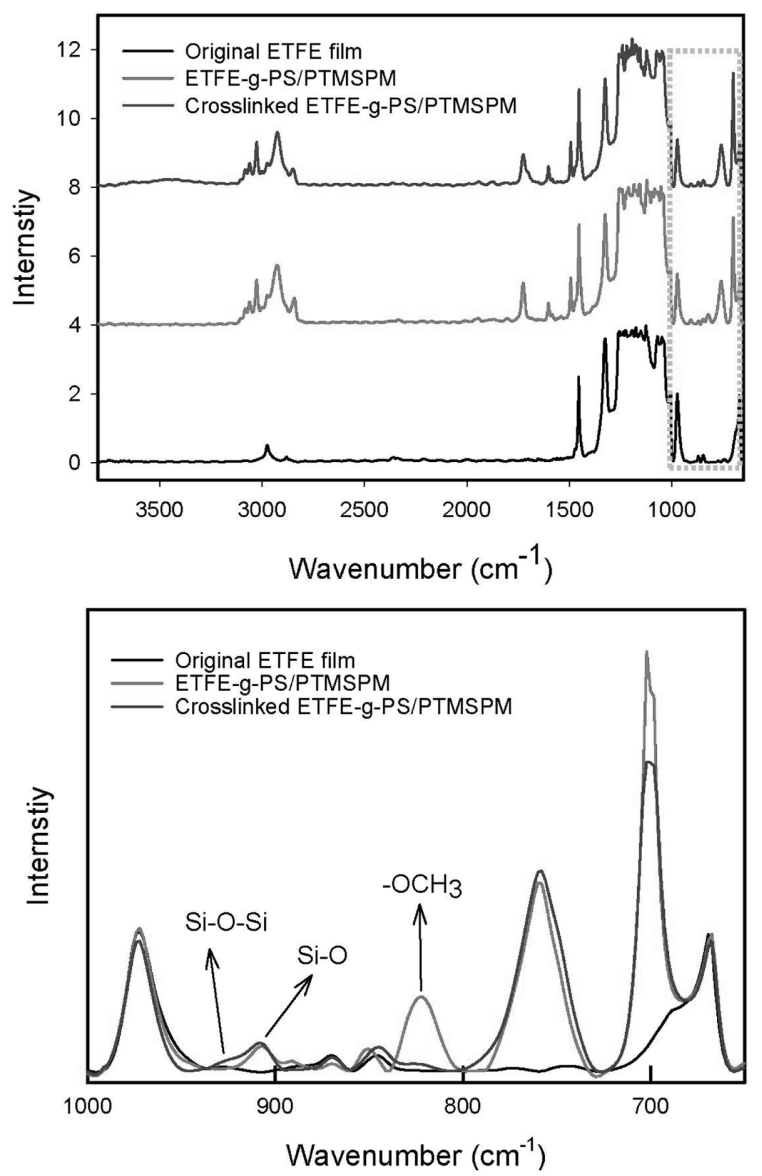

Figure 1. FTIR spectra of ETFE film, ETFE- $g$-PS/PTMSPM film and silane-crosslinked ETFE-g-PS/PTMSPM film (bottom spectra are expanded for clarification).
와 $\mathrm{Si}-\mathrm{O}$ 결합의 의한 진동피크를 830 및 $910 \mathrm{~cm}^{-1}$ 에서 각각 관찰할 수 있었고 스티렌이 그래프트되면서 나타나는 방향족 mono 치환기의 out of plant(OOP)의 피크를 $800 \sim 680 \mathrm{~cm}^{-1}$ 에 서 관찰할 수 있어 스티렌과 TMSPM이 동시에 그래프트 사 슬을 형성하고 있음을 확인할 수 있었다. 졸젤 반응 후에 제 조된 필름에서는 메톡시 $\left(-\mathrm{OCH}_{3}, 830 \mathrm{~cm}^{-1}\right)$ 그룹의 피크가 사 라지고 $\mathrm{Si}-\mathrm{O}-\mathrm{Si}$ 결합의 피크가 $928 \mathrm{~cm}^{-1}$ 에서 새로 형성됨을 관찰할 수 있어 가교 구조가 형성되었음을 관찰할 수 있었다. 한편, 하이드록시 $(-\mathrm{OH})$ 결합에 의한 피크가 $3400 \mathrm{~cm}^{-1}$ 에서 미 세하게 관찰되었는데 이는 졸젤 반응 과정에서 산 촉매 가수 분해 이후 축합반응에 참여 못한 $\mathrm{Si}-\mathrm{OH}$ 그룹이 소량 잔류하 기 때문에 나타나는 것으로 판단된다. ${ }^{16,19}$

Figure 2는 St/TMSPM 7/3, 5/5 (v/v) 조성비로 그래프트시킨 필름들과 이후 졸-젤 반응을 진행시킨 필름들의 $\mathrm{TGA}$ 측정 결 과를 나타낸 것이다. 모든 필름의 $\mathrm{TGA}$ 곡선을 보면 온도가 증가함에 따라 두 단계의 무게 변화를 관찰할 수 있다. 첫 번 째 무게변화는 약 $400{ }^{\circ} \mathrm{C}$ 부근에서 스티렌 및 TMSPM 단량 체들이 형성한 그래프트 사슬의 분해로 인한 것이며, 두 번째
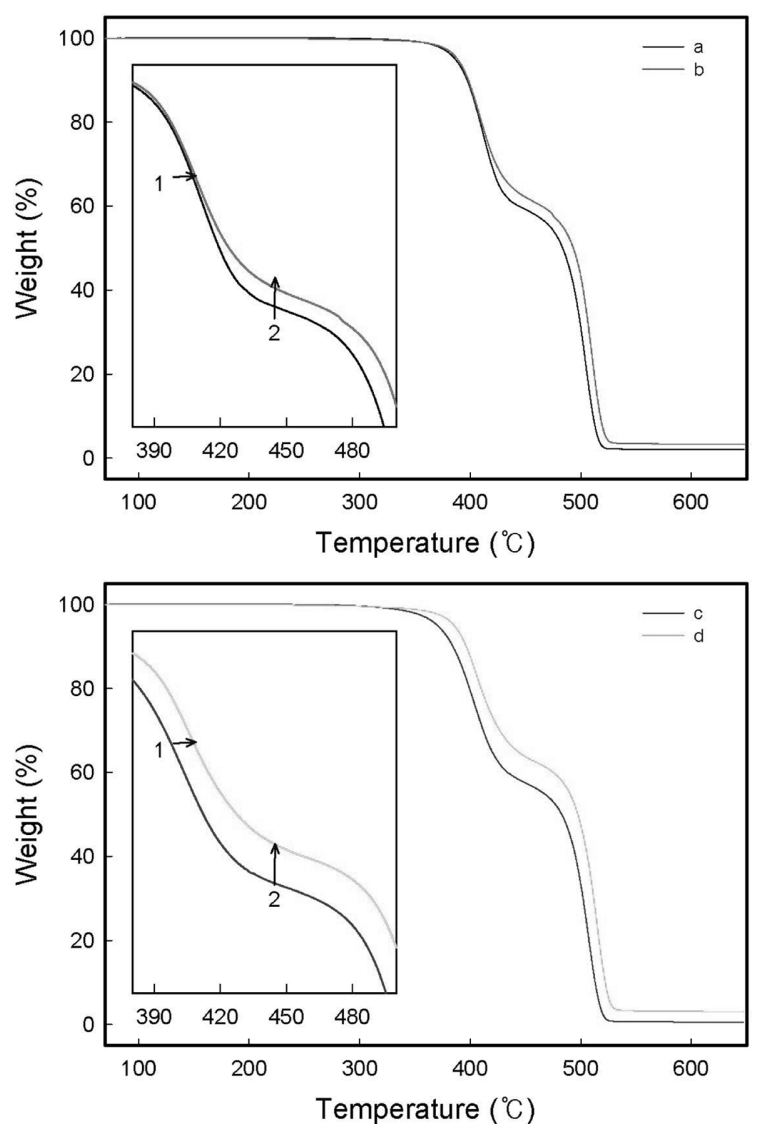

Figure 2. TGA thermograms of the prepared membranes before and after silane crosslinking (a) ETFE-g-PS/PTMPM 7/3 (v/v); (b) crosslinked ETFE-g-PS/PTMPM 7/3 (v/v); (c) ETFE-g-PS/PTMPM 5/5 (v/v); (d) crosslinked ETFE-g-PS/PTMPM 5/5 (v/v). 
무게변화는 약 $500{ }^{\circ} \mathrm{C}$ 부근에서 $\mathrm{ETFE}$ 주사슬의 분해 때문이 다. TMSPM 조성이 다른 그래프트 필름을 비교할 경우, $\mathrm{TMSPM}$ 의 조성비가 클수록 그래프트 고분자 사슬의 분해온 도가 감소함을 확인하였다. 한편, $30 \% \mathrm{TMSPM}$ 조성비로 그 래프트된 필름을 이용하여 졸젤 반응을 진행시킬 경우, 그래 프트 사슬에 의한 분해 온도가 반응 전 후 큰 변화가 없는 반 면 $50 \% \mathrm{TMSPM}$ 조성비로 그래프트된 필름을 이용하여 졸젤 반응을 진행시킬 경우, 약 $10^{\circ} \mathrm{C}$ 정도 분해온도가 증가되 는 것을 관찰할 수 있었다. 위와 같은 결과는 낮은 조성비의 TMSPM으로 그래프트된 필름의 경우 졸-젤 반응을 진행하여 도 실란 가교 구조 형성이 원활하게 이루어 지지 않고 높은 조성비로 그래프트된 필름의 경우 같은 졸젤 반응 조건에서 실란 가교 구조 형성이 원활하게 진행됨을 보여준다. ${ }^{21}$ 또한 졸-젤 반응 전 후 TMSPM 조성비가 7/3에서 5/5로 증가할수 록 그래프트 사슬과 ETFE 주사슬의 상대적 무게 변화의 차 이가 증가되는 것을 관찰할 수 있었다. 이는 졸젤 반응 과정 을 통하여 실란 가교 구조를 형성할 경우, TMSPM의 메톡시 그룹이 산 촉매 가수분해로 인해 $\mathrm{Si}-\mathrm{OH}$ 그룹으로 치환되고 이후 축합반응으로 $\mathrm{Si}-\mathrm{O}-\mathrm{Si}$ 형태의 가교 구조를 형성함에 따 라 그래프트 사슬의 무게를 감소시키기 때문으로 여겨진다. 따라서 TGA 실험 결과, TMSPM $5 / 5$ 조성비로 그래프트된 필름은 졸-젤 반응을 통해 실란 가교 구조 형성이 원활이 진 행됨을 확인할 수 있었다.

Figure 3은 졸젤 반응 이후 설폰산 작용기를 도입하여 제조 된 수소이온교환막의 기계적 강도를 보여주고 있다. TMSPM 을 첨가하지 않고 스티렌으로 그래프트된 수소이온교환막 $(\mathrm{St} / \mathrm{TMSPM}(10 / 0))$ 의 최고 인장강도와 인장률은 $47 \mathrm{MPa}$ 과 $250 \%$ 로 측정되었으며 $30 \% \mathrm{TMSPM}$ 을 사용하여 제조된 막 $(\mathrm{St} / \mathrm{TMSPM}(7 / 3))$ 의 인장강도와 인장률은 $48 \mathrm{MPa}$ 과 $208 \%$ 로 측정되었다. $50 \%$ 의 $\mathrm{TMSPM}$ 을 사용하여 제조된 막 $(\mathrm{St} /$ $\mathrm{TMSPM}(5 / 5))$ 의 인장강도와 인장률은 $50 \mathrm{MPa}$ 과 $159 \%$ 로 측

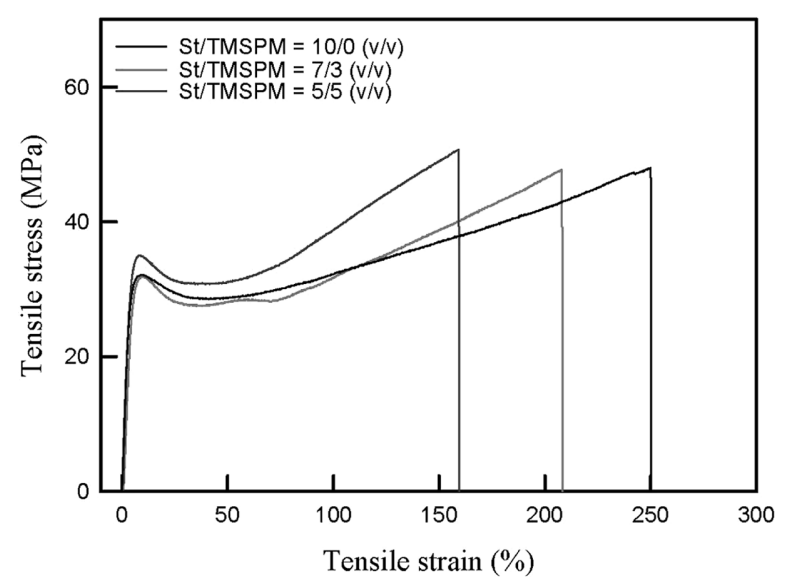

Figure 3. Stress-strain curves of crosslinked ETFE- $g$-PSSA/PTMSPM membranes prepared with different TMSPM contents.
정되었다. 이는 TMSPM의 조성비를 증가시킬수록 제조된 수 소이온교환막의 실란 가교 구조가 증가하게 되어 기계적 강도 는 증가하지만 인장률은 감소하고 있음을 확인할 수 있었다.

Figure 4는 상대습도 $90 \%$ 에서 제조된 수소이온교환막들의 온도에 따른 수소이온전도도 변화를 측정한 결과이다. 제조된 막들은 측정 온도가 증가함에 따라 수소이온전도도가 증가하 는데 이는 온도가 증가함에 따라 고분자 사슬의 움직임 및 수소 이온의 움직임이 증가하기 때문에 일어나는 현상이다. 측정된 막들은 비슷한 IEC 값을 가지고 있지만 Table 1에서 나타나듯이 $30 \%$ 의 $\mathrm{TMSPM}$ 조성비로 제조된 막은 가교에 참여하지 못하고 잔류하고 있는 $-\mathrm{Si}-\mathrm{OH}$ 그룹 때문에 함수율 이 높아 다른 조성의 막보다 높은 수소이온전도도를 가지는 것으로 여겨진다. TMSPM 함량이 $50 \%$ 로 증가하였을 경우에 는 TMSPM 함량 $30 \%$ 보다 실란 가교가 많이 되기 때문에 상대적으로 낮은 이온전도도를 가지지만 가교에 참여하지 않 은 미반응된 $-\mathrm{Si}-\mathrm{OH}$ 그룹이 존재하여 막의 친수성을 증가시 켜 TMSPM을 함유하고 있지 않은 수소이온교환막보다 높은 수소이온전도도를 보이는 것으로 여겨진다.

Figure 5는 제조된 수소이온교환막을 이용하여 $\mathrm{MEA}$ 를 제 조한 후 $80{ }^{\circ} \mathrm{C}$ 에서 단위전지 성능을 측정한 결과를 전류-전압 곡선으로 나타낸 결과이다. TMSPM $30 \%$ 조성비로 제조된 막을 이용한 단위전지의 전류밀도는 $0.6 \mathrm{~V}$ 에서 $819 \mathrm{~mA} / \mathrm{cm}^{2}$ 로 가장 높은 값을 보였고 최대 전력밀도 또한 $\mathrm{TMSPM}$ 의 조성비 $30 \%$ 에서 $631 \mathrm{~mW} / \mathrm{cm}^{2}$ 으로 가장 높은 값을 보여주었 다. 이는 TMSPM 조성비 $30 \%$ 로 제조된 막이 가장 높은 함 수율 및 수소이온전도도를 가지고 있기 때문에 높은 성능을 보여주는 것으로 여겨진다. 이에 반해 TMSPM 조성비 50\% 로 제조되어 실란 가교 밀도가 가장 높은 막은 TMSPM 없 이 스티렌으로만 제조된 막보다 높은 수소이온전도도를 가지 고 있음에도 상대적으로 낮은 전류밀도와 전력밀도를 보여주 었다. 이러한 수소이온전도도와 단위전지 성능과의 차이는

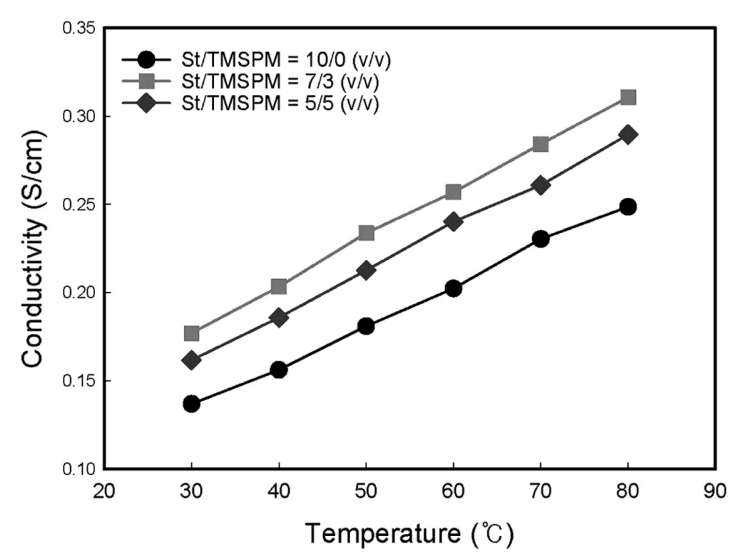

Figure 4. Effect of temperature on the proton conductivity of crosslinked ETFE- $g$-PSSA/PTMSPM membranes prepared with different TMSPM contents. 


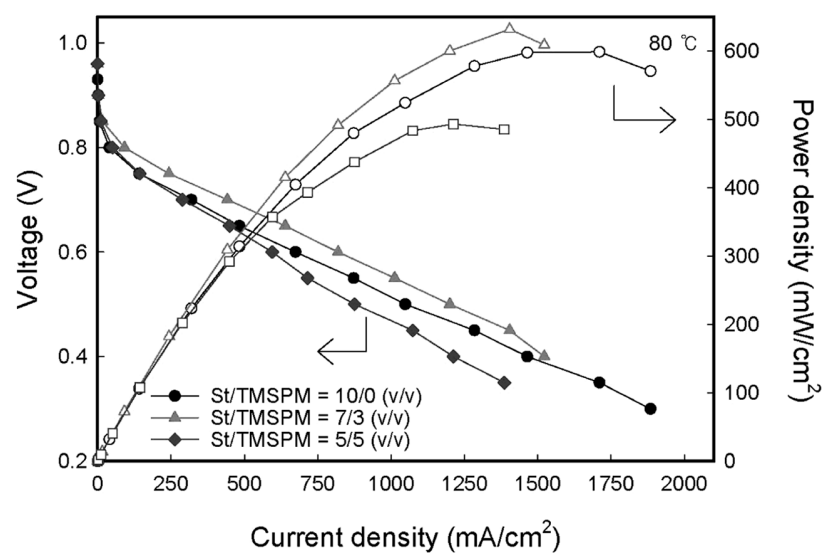

Figure 5. Polarization curves of the single cell with crosslinked ETFE- $g$-PSSA/PTMSPM membranes at $80^{\circ} \mathrm{C}$.

MEA 조립 시 사용되는 바인더와의 상용성 및 계면 접착성 등 여러 요인이 작용하여 발생한 것으로 여겨지며 이에 대한 추가적인 연구가 진행될 예정이다. 이전 연구에서는 ${ }^{20}$ 실란 가교 구조가 막의 화학적 안정성 및 치수 안정성 등을 향상 시키는 것을 확인하였고, 본 연구에서는 실란 가교 구조가 막 의 열적 안정성 및 기계적 물성 향상과 함께 TMSPM $50 \%$ 조성비로 제조하여 실란 가교 구조를 형성한 막의 경우 $0.6 \mathrm{~V}$ 에서 $595 \mathrm{~mA} / \mathrm{cm}^{2}$ 전류밀도와 $493 \mathrm{~mW} / \mathrm{cm}^{2}$ 의 최대 전력 밀도를 얻을 수 있음을 확인하였다.

\section{결 론}

본 실험에서는 동시조사 방법으로 ETFE 필름에 스티렌과 $\mathrm{TMSPM}$ 을 그래프트시킨 후 졸-젤 반응을 진행하여 실란 가 교 구조를 갖는 필름을 제조하였다. 제조된 그래프트 필름 및 실란 가교 구조를 갖는 필름의 FTIR 및 TGA 실험을 진행하 여 실란 가교 구조 형성 여부를 관찰한 결과 TMSPM $30 \%$ 의 조성비로 제조된 필름의 경우 실란 가교 구조 형성이 미 비한 것으로 여겨지며 TMSPM $50 \%$ 조성비로 제조된 필름 은 실란 가교 구조 형성을 이루고 있음을 관찰할 수 있었다. 설폰화 과정을 진행하여 $\mathrm{PEMFC}$ 에 사용되는 수소이온교환막 을 제조하였고 TMSPM의 조성비가 다르지만 유사한 IEC 값 을 갖는 시료 3 개를 선정하여 막의 특성 평가를 진행하였다. TMSPM의 함량이 많을수록 실란 가교로 인해 인장률은 낮아 지지만 인장강도는 증가되는 것을 확인하였다. MEA 단위전 지 성능 평가 결과 TMSPM $30 \%$ 의 조성비로 제조된 막이 높은 최대 전력밀도와 $0.6 \mathrm{~V}$ 에서 높은 전류밀도를 보임을 확 인하였고 TMSPM $50 \%$ 의 조성비로 제조되어 실란 가교 구 조를 형성하고 있는 막의 경우 상대적으로 낮은 전력밀도와 전류밀도를 보이는 것을 확인하였다. 하지만, 실란 가교 구조 가 연료전지막의 물성 향상에 미치는 긍정적인 영향을 고려
하면 연료전지막의 내구성 향상에 유용하게 사용될 것으로 기대된다.

감사의 글: 본 연구는 교육과학기술부 재원으로 원자력연구 개발사업의 지원을 받아 수행하였다.

\section{참 고 문 헌}

1. J.-S. Kim, R. J. Jackman, and A. Eisenberg, Macromolecules, 27, 2789 (1994).

2. J.-P. Shin, B.-J. Change, J.-H. Kim, S.-B. Lee, and D.-H. Suh, J. Membr. Sci., 251, 247 (2005).

3. S. Kang, D.-H. Peck, S.-K. Kim, S. Lim, D. Jung, Y.-C. Park, J. Shin, P.-H. Kang, Y.-C. Nho, and Y. Shul, J. Korean Electrochem. Soc., 12, 173 (2009).

4. J.-M. Song, J. Shin, J.-Y. Sohn, and Y.-C. Nho, Macromol. Res., 19, $1082(2011)$.

5. J.-H. Choi, P.-H. Kang, Y.-M. Lim, J.-Y. Sohn, J. Shin, C.-H. Jung, J.-P. Jeun, and Y.-C. Nho, Korean Membrane J., 9, 52 (2007).

6. B.-S. Ko, J. Shin, J.-Y. Sohn, Y.-C. Nho, and P.-H. Kang, Polymer(Korea), 33, 268 (2009).

7. B.-S. Ko, S.-A. Kang, G. Fei, J.-P. Jeun. Y.-C. Nho, P.-H. Kang, C.-Y. Kim, and J. Shin, Polymer(Korea), 34, 20 (2010).

8. S. A. Gursel, L. Gubler, B. Gupta, and G. G. Scherer, $A d v$. Polym. Sci., 215, 157 (2008).

9. A. Bhattacharya and B. N. Misra, Prog. Polym. Sci., 29, 767 (2004).

10. M. M. Nasef and E.-S. A. Hegazy, Prog. Polym. Sci., 29, 449 (2004).

11. S.-A. Kang, J. Shin, G. Fei, B.-S. Ko, C.-Y. Kim, and Y.-C. Nho, Nucl. Instrum. Meth. Phys. Res. B, 268, 3458 (2010).

12. F. N. BuÈchi, B. Gupta, O. Haas, and G. G. Scherer, Electrochim. Acta, 40, 345 (1995).

13. S.-A. Kang, J. Shin, G. Fei, B.-S. Ko, C.-Y. Kim, Y.-C. Nho, and P.-H. Kang, J. Ind. Eng. Chem., 15, 516 (2009).

14. J. Chen, D. Li, H. Koshikawa, M. Asano, and Y. Maekawa, J. Membr. Sci., 362, 488 (2010).

15. J. Chen, M. Asano, Y. Makawa, and M. Yoshida, J. Membr. Sci., 296, 77 (2007).

16. J. Chen, M. Asano, Y. Makawa, and M. Yoshida, J. Polym. Sci. Part A: Polym. Chem., 46, 5559 (2008).

17. R. K. Nagarale, G. S. Gohil, V. K. Shahi, and R. Rangarajan, Macromolecules, 37, 10023 (2004).

18. R.-O. Fu, J.-J. Woo, S.-J. Seo, J.-S. Lee, and S.-H. Moon, J. Power Sources, 179, 458 (2008).

19. H.-J. Sung, J.-Y. Sohn, J.-M. Sung, J. Shin, and Y.-C. Nho, Polymer(Korea), 35, 478 (2011).

20. J.-Y. Sohn, H.-J. Sung, J. Shin, B.-S. Ko, J.-M. Song, and Y.-C. Nho, Macromol. Res., DOI: 10.1007/s13233-012-0131-1 (2012).

21. H. Lin, C. Zhao, Y. Jiang, W. Ma, and H. Na, J. Power Sources, 196, 1744 (2011). 